\title{
Distribution and abundance of the Red Squirrel Sciurus vulgaris in an urbanised environment
}

Grzegorz Kopij

Distribution and abundance of the Red Squirrel Sciurus vulgaris in an urbanised envirnonment. - Acta Mus. Siles. Sci. Natur., 63: 255-262, 2014.

\begin{abstract}
In late autumn 2004, 160 dreys were found in all parks in Wroclaw ( $\mathrm{N}=21$ parks), i.e. 2.8 dreys per 10 ha. In the same period, 145 squirrels, grouped in 69 families, were counted in all these parks (1.23 families per $10 \mathrm{ha}$ ). The mean group size (including records of single squirrels) was 1.93 ( $S D=1.04 ; N=157$ ). The density estimate based on this (number of dreys/mean number of dreys per group) shall be 1.40 families per 10 ha, therefore close to the value based on the number of squirrels counted. Squirrels were most common (64\% of all squirrels recorded in parks) in largest parks located c. 2-7 km from the city centre. In forests $(\mathrm{N}=12)$, squirrels density was much lower than in parks (0.1-0.3 families per $10 \mathrm{ha})$.
\end{abstract}

Key words: urban ecology, dreys, habitat, population density, Hooded Crow predation.

\section{Introduction}

The Red Squirrel Sciurus vulgaris is a rodent species widespread in Europe. It is regarded as a common in forests and larger urban parks all over Poland (Pucek 1983; Babińska-Werka \& Żółw 2008). Recently, in many European countries a sharp decline of this species has been, however, recorded. In Poland, no such data are available from forests, while population density estimation in cities has been conducted so far only in Warsaw (Babińska-Werka \& Żółw 2008). In addition, counts were conducted using one method, only in a few selected urban parks and forests, so that to estimate the population size in the whole city was impossible.

The aim of this study was to record distribution and numbers of the Red Squirrels in all suitable habitats within the administrative boundaries of the city of Wroclaw, SW Poland. This has been done in order to estimate population size, not only in particular habitats, but also in the whole city. An attempt has also been undertaken to analyze factors controlling the distribution and numbers of this species in urbanized habitats.

\section{Study area}

Counts were conducted in all parks and forests, and some larger tree hedgerows and other timbered areas within administrative boundaries of the city of Wrocław, SW Poland. The total surface area of the city within its administrative boundaries is $290 \mathrm{~km}^{2}$.

The parks range in size from 10 to 120 ha $(\mathrm{N}=20)$. In most parks, mature and old oaks Quercus spp., limes Tilia cordata, maples Acer spp. and hornbeams Carpinus betulus predominate. Trees such as birch Betula verrucosa, ash Fraxinus excelsior, beech Fagus sylvatica, locust Robinia pseudoacacia, spruces Picea spp., alders Alnus spp., poplars Populus spp., pines Pinus spp., and others comprise admixture.

Forests range in size from 9 to 557 ha $(\mathrm{N}=13)$. Most of them retain the character of hornbeam stand, but some are altered with pine and spruce (Mokrzański, Leśniński, Rakowiecki). While in some of them the tree stand is old and well preserved (Wyspa Opatowicka, Wojnowski, Osobowicki, Rędziński, Lesicki), in others most old trees were removed, so that today maturing stages predominate.

Most hedgerows in Wroclaw fall below 1 ha. Larger are located in Odra II wetlands, Wielka Wyspa, and in Dolina Bystrzycy Landscape Park. In the city centre, Zoological and Botanic Gardens are situated. Old hornbeam stand predominates, but there is also large amount of exotic trees and shrubs in these parks. 


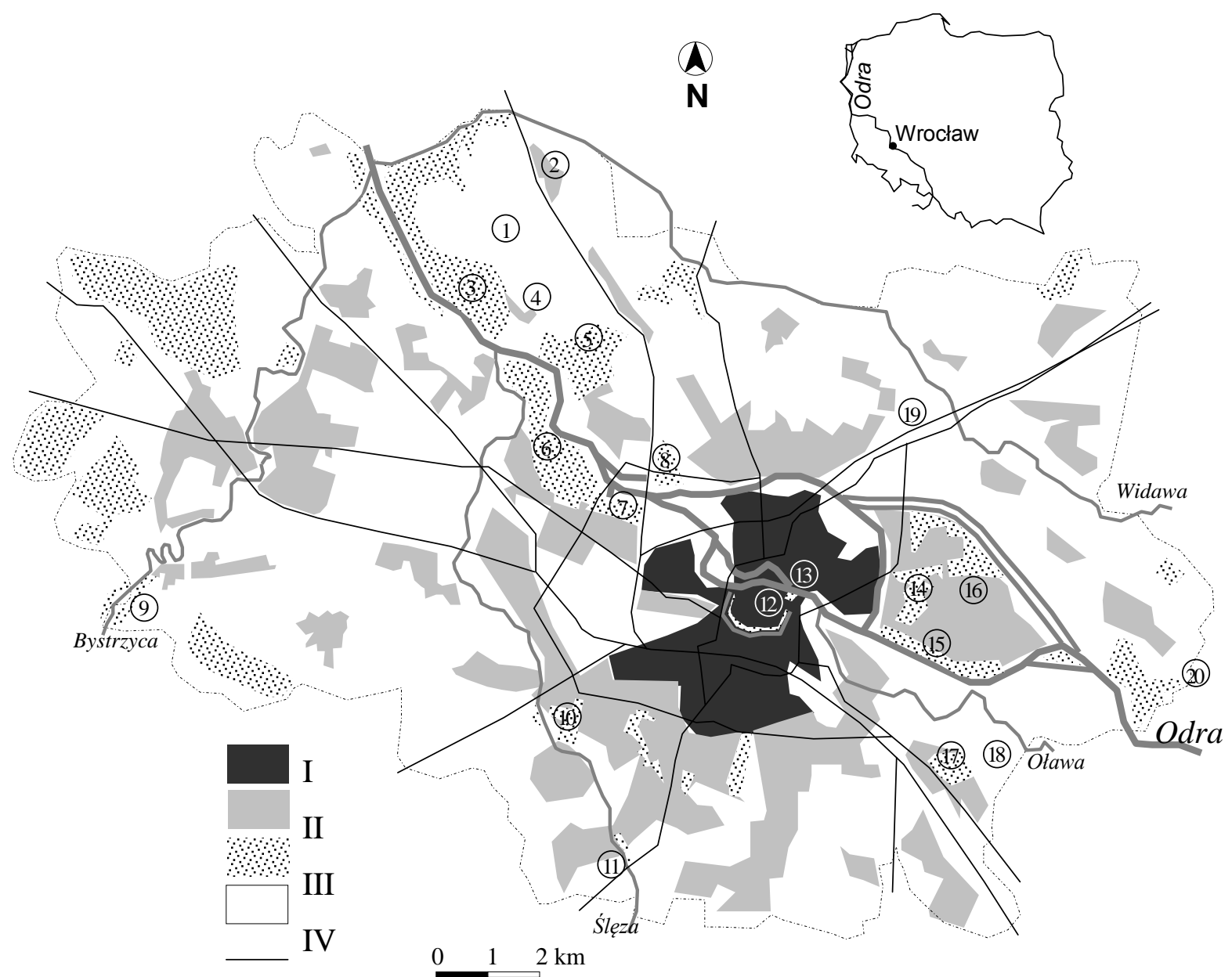

Fig 1: Map of Wroclaw. Main land-use forms: I - densely built-up city centre, II - loosely built-up areas, III greenery areas (forests, parks, cemeteries), IV - farmland (arable grounds, meadows, pastures, allotment gardens), V - main roads. Arabic numbers indicate some important places: 1 - Swiniary irrigation fields, 2 Świniary, 3 - Rędziński Forest, 4 - Rędzin, 5 - Osobowicki Forest, 6 - Pilczycki forest and Zachodni Park, 7 Popowicki Park, 8 - Osobowice Cemetry, 9 - Dolina Bystrzycy Lanscape Park, 10 - Grabiszyński Park, 11 Klecina, 12 -Słowacki Park, 13 - Botanic Garden 14 - Szczytnicki Park, 15 - Zoological Garden, 16 - Wielka Wyspa, 17 - Wschodni Park, 18 - Odra II wetlands, 19 - Sołtysowice, 20 - Wojnów-Dobrzykowice irrigation fields.

\section{Methods}

Four methods are available to estimate population density of the Red Squirrel: 1) counting individuals, 2) counting dreys (outside coniferous forests), 3) counting feeding sites on foraging transects (only in coniferous forests), and 4) offering corn-cobs (only to record squirrel presence) (Gurnell et al. 2001, 2004). Only the two first methods can be employed in broad-leaved or mixed parks and forests. The two methods were, therefore, employed to estimate the squirrel population density. Counts were conducted in all parks, forests and larger tree clumps within the administrative boundaries of the city of Wroclaw.

The Red Squirrel builds a spherical nest, so called drey, composed of dry leafy twigs and bast. It is c. $30 \mathrm{~cm}$ in diameter and is located usually on the top of such trees as oak Quercus robur, lime Tilia cordata, hornbeam Carpinus betulus, birch Betula verrucosa (Kopij 2009). They are usually easy to discover in late autumn, when most trees are without leaves.

During the year, the Red Squirrel is the most numerous in autumn (September-October), the least numerous - in early spring (March-April)(Wauters et al., 2001; Lurz et al. 2005; Babińska-Werka \& Żółw 2008), hence the most suitable season of the year to count squirrels is autumn. In this study, squirrels were counted in parks in early autumn (September-October) 2004, and their dreys in late autumn (November-December) 2004.

Counts of squirrels were conducted on transects, which were fixed in a way to record all individuals, but to exclude double counting. In most cases, they run c. $50 \mathrm{~m}$ parallel to each other. Counts were conducted under sunny and windless weather. 
In forests and larger hedgerows, both squirrels and dreys were counted in all months during the years 20042006. In each group, the number of squirrels were also counted. Both group and isolated single individuals were regarded as representing a family.

\section{Results}

All squirrels recorded in Wroclaw belonged to the red phase. In late autumn 2004, 160 dreys were found in all parks in Wroclaw ( $\mathrm{N}=21$ parks), i.e. 2.8 dreys per 10 ha (Table 1). In the same period, 145 squirrels, grouped in 69 families, were counted in the same parks, i.e. 2.6 individuals per 10 ha or $\mathbf{1 . 2}$ families per 10 ha. The average number of dreys per family was 2.1. Red Squirrels were observed, usually in pairs or singly in Wrocław, and only occasionally groups of 3-6 individuals were recorded (Fig. 2-4). The mean group size (including records of single squirrels) was 1.9 ( $\mathrm{SD}=1.04 ; \mathrm{N}=81$ groups).

Red Squirrels were most common (64\% of all squirrels recorded in parks) in largest parks located c. 2-7 km from the city centre (i.e. Zachodni, Grabiszyński, Południowy, Skowroni, Andersa). They were fairly common (19\% of all park squirrels) in Szczytnicki, Biskupinski and Zoological Garden, which together form almost an unbroken belt of slightly modified old stand of the hornbeam forest. They were not recorded in parks located in the city centre (0-2 $\mathrm{km}$ from the city hall), such as Słowackiego, Kopernika, Nowowiejski, Staszica, Kasprowicza and Dąbrowskiej. Those are small, highly modified parks, with a high visit frequency of human, dogs and cats. In parks located on the city periphery (parameters), such as Wschodni, Złotnicki, Leśnicki and Stabłowicki, the density of squirrels was low.

In forests $(\mathrm{N}=12)$, density of the Red Squirrel was much lower than in parks. Both records of individuals as well as dreys were uncommon and isolated. It can be assumed that the number of families recorded $(\mathrm{N}=14)$ there was roughly equal to that of dreys found $(\mathrm{N}=$ 12). The mean density will be 0.1 drey or 0.1 family per 10 ha of forest. Some individuals and dreys could pass there undetected, this value should be, therefore, regarded as a minimum. The maximum value may be assumed as 0.3 drey (or 0.3 family) per 10 ha.

Single dreys and/or single squirrels were also recorded in seven larger hedgerows. The density (1.6 family per 10 ha) were similar to that recorded in the parks; a few families could pass undetected.

In overall, the total number of the Red Squirrel families in Wrocław is estimated at 90 $120,67-77 \%$ of which occur in parks. The mean density is therefore $0.36-0.54$ families per 10 ha of afforested area.

\section{Discussion}

Under natural conditions, larger forests (2000-5000 ha) are the most optimal habitat for the Red Squirrel, but population may inhabit even much smaller forests ( $<100$ ha) (Lurz et al. 2005). In the British Islands, the average long-term squirrel density ranged from 5 to 15 individuals per $10 \mathrm{ha}$; in coniferous forest of Scandinavia it ranged from 0.2 to 2.0 individuals / 10 ha. However, a marked year-to-year fluctuations caused by weather conditions and seed abundance are known in these regions. From urban areas data on population densities are only available from Warsaw, where in urban parks the squirrel's density changes from 4 to 18 individuals per 10 ha, and in city forests - from 0.1 to 0.3 individuals per 10 ha (BabińskaWerka \& Żółw 2008). In Wrocław parks, the average density was 2.6 individuals per 10 ha, ranging from 0.0 to 10.0 (Table 1). The highest was recorded in Skowroni and Andersa Parks (8.4 and 10.0 ind./10 ha respectively). 
Tab 1: Number of squirrels in parks and forests in the city of Wrocław in 2004-2005.

\begin{tabular}{|c|c|c|c|c|c|c|c|}
\hline Park/forest name & Acrage & & & Ind & duals & & \\
\hline & [ha] & $\mathrm{N}$ & N/10 ha & $\mathrm{N}$ & $\mathrm{N} / 10$ ha & $\mathrm{N}$ & $\mathrm{N} / 10$ ha \\
\hline Suburb parks & 563 & 160 & 2.8 & 145 & 2.6 & 69 & 1.2 \\
\hline Słowackiego & 10 & 0 & 0.0 & 2 & 2.0 & 1 & 1.0 \\
\hline Kopernika & 3 & 0 & 0.0 & 0 & 0.0 & 0 & 0.0 \\
\hline Nowowiejski & 5 & 0 & 0.0 & 0 & 0.0 & 0 & 0.0 \\
\hline Staszica & 12 & 0 & 0.0 & 0 & 0.0 & 0 & 0.0 \\
\hline Kasprowicza & 5 & 0 & 0.0 & 2 & 4.0 & 1 & 2.0 \\
\hline Dąbrowskiej & 9 & 0 & 0.0 & 0 & 0.0 & 0 & 0.0 \\
\hline Sołtysowicki & 22 & 0 & 0.0 & 2 & 0.9 & 1 & 0.5 \\
\hline Pawłowicki & 73 & 0 & 0.0 & 1 & 0.1 & 1 & 0.1 \\
\hline Szczytnicki & 110 & 17 & 1.5 & 16 & 1.5 & 9 & 0.8 \\
\hline Biskupiński & 17 & 4 & 2.4 & 7 & 4.1 & 4 & 2.4 \\
\hline Wschodni & 40 & 1 & 0.3 & 1 & 0.3 & 1 & 0.3 \\
\hline Popowicki & 18 & 4 & 2.2 & 7 & 3.9 & 4 & 2.2 \\
\hline Zachodni & 75 & 57 & 7.6 & 39 & 5.2 & 15 & 2.0 \\
\hline Grabiszyński & 48 & 22 & 4.6 & 15 & 3.1 & 8 & 1.7 \\
\hline Południowy & 20 & 18 & 9.0 & 11 & 5.5 & 6 & 3.0 \\
\hline Skowroni & 25 & 28 & 11.2 & 21 & 8.4 & 8 & 3.2 \\
\hline Andersa & 15 & 7 & 4.7 & 15 & 10.0 & 7 & 4.7 \\
\hline Kleciński & 10 & 0 & 0.0 & 2 & 2.0 & 1 & 1.0 \\
\hline Złotnicki & 20 & 1 & 0.5 & 2 & 1.0 & 1 & 0.5 \\
\hline Leśnicki & 20 & 1 & 0.5 & 2 & 1.0 & 1 & 0.5 \\
\hline Stabłowicki & 6 & 0 & 0.0 & 0 & 0.0 & 0 & 0.0 \\
\hline Forests & 1626 & 12 & 0.1 & 16 & 0.1 & 14 & 0.1 \\
\hline Wroni & 10 & 2 & 2.0 & 3 & 3.0 & 2 & 2.0 \\
\hline Wyspa Opatowicka & 30 & 1 & 0.3 & 1 & 0.3 & 1 & 0.3 \\
\hline Rakowiecki & 22 & 0 & 0.0 & 1 & 0.5 & 1 & 0.5 \\
\hline Strachociński & 139 & 2 & 0.1 & 3 & 0.2 & 3 & 0.2 \\
\hline Wojnowski & 18 & 0 & 0.0 & 0 & 0.0 & 0 & 0.0 \\
\hline Kuźnicki & 9 & 0 & 0.0 & 0 & 0.0 & 0 & 0.0 \\
\hline Pilczycki & 100 & 0 & 0.0 & 0 & 0.0 & 0 & 0.0 \\
\hline Osobowicki & 138 & 3 & 0.2 & 3 & 0.2 & 3 & 0.2 \\
\hline Rzędziński and Lesicki & 407 & 1 & 0.0 & 1 & 0.0 & 1 & 0.0 \\
\hline Mokrzański & 551 & 2 & 0.0 & 2 & 0.0 & 1 & 0.0 \\
\hline Leśnicki & 38 & 0 & 0.0 & 0 & 0.0 & 0 & 0.0 \\
\hline Ratyński & 164 & 1 & 0.1 & 2 & 0.1 & 2 & 0.1 \\
\hline Other timbered areas & 57 & 3 & 0.5 & 9 & 1.6 & 8 & 1.4 \\
\hline Zoological Garden & 30 & 1 & 0.3 & 4 & 1.3 & 3 & 1.0 \\
\hline Botanic Garden & 7 & 0 & 0.0 & 0 & 0.0 & 0 & 0.0 \\
\hline Near Olimpic Stadium, Sępolno & 2 & 2 & 10.0 & 1 & 5.0 & 1 & 5.0 \\
\hline Near WTWK, Partynice & 3 & 0 & 0.0 & 1 & 3.3 & 1 & 3.3 \\
\hline Pld. and Grabiszyński Park & 3 & 0 & 0.0 & 1 & 3.3 & 1 & 3.3 \\
\hline Near ‘Spartakus’, Sępolno & 2 & 0 & 0.0 & 1 & 5.0 & 1 & 5.0 \\
\hline Leśnicki and Stabłowicki Park & 10 & 0 & 0.0 & 1 & 1.0 & 1 & 1.0 \\
\hline Total & 2219 & 175 & 0.8 & $\mathbf{1 7 0}$ & 0.8 & 91 & 0.4 \\
\hline
\end{tabular}


It looks as if the squirrel population density in urban parks is higher in Warsaw than in Wrocław. Authors do not provide any information on the selection procedure of their study plots in Warsaw. Population density of the squirrel has been estimated there only in 5 out off 82 parks (6.1\%) (Babińska-Werka \& Żółw 2008). The average could have been biased (overestimated) as parks with higher squirrel's populations were probably selected (they are all relatively large and situated in the city centre), while avoided were those with low squirrel's densities. If this holds true, the population density of the squirrel in urban parks will be quite similar in both cities compared.

To date, no data have been available on population density of the Red Squirrel in the city of Wrocław. However, it is known that in the 1970's it was much numerous in some areas, such as Słowacki Park (Tomiałojć 2011) and Botanic Garden (Kopij, Zendwalewicz 2009), where it does not occur today. Probably, it was more numerous also in Szczytnicki Park (Tomiałojć 2011). It has been recorded that the Red squirrel was commoner when the Pine Marten Martes martes did not occur there (Tomiałojć 2011). The Pine Marten is, however, rather a rare species in Wrocław parks (own observ.). In urbanized habitats, the cat is regarded as the most important predator of the squirrel; with dog, fox, marten, ermine, buzzard, goshawk and owls to much lesser extend (Lurz et al. 2005). It is more probable, that disappearance of the Red Squirrel from parks in the city centre of Wrocław, is coincided with other common and expanding predator: the Hooded Crow Corvus cornix. It not only mobs squirrels, but may also kill them. The Hooded Crow did not occur in both Słowacki Park and in Botanic Garden in the 1970's (Kopij, Zendwalewicz 2009; Tomiałojć 2011), when the Red Squirrels were common. At present, 7-8 pairs nests in the Słowacki Park (Tomialojc 2011), and 4 pairs in the Botanic Garden (Kopij, Zendwalewicz 2009) were recorded, while the Red Squirrel is virtually absent there. The Hooded Crow is a numerous breeding bird also in other parks in the city centre, such as Kopernika, Nowowiejski, Staszica or Kasprowicza (Kopij 2005, 2007), where the Red Squirrel was not recorded. In some large parks (i.e. Szczytnicki or Wschodni), where the Hooded Crow also commonly nests, the population density of the Red Squirrel is much lower than in those large park (i.e. Zachodni, Grabiszyński, Południowy, Skowroni, Andersa) were density of nesting Hooded Crows is much lower (Kopij 2010, Kopij in prep.).

Parks, especially the larger ones (Grabiszyński, Południowy, Skowroni, Andersa or Biskupiński), located close to allotment gardens, hold larger populations of the Red Squirrels than parks (Złotnicki, Leśnicki, Stabłowicki), which do not border with them. Allotment gardens may provide good feeding base for squirrels, especially in autumn and early winter. In Warsaw, the highest population density was also recorded in larger parks located in the city centre, with Łazienki Park holding the largest population, i.e. 119 individuals in 2005 (Babińska-Werka \& Żółw 2008).

The size of park, its distance from other parks, and the composition and age of trees may also affect the occurrence and the population size of the Red Squirrel. In large parks, with diverse old tree stands (dominated by species such as oaks, beeches, limes, hornbeams, pines and spruces), connected with allotment gardens or tree belts, the population density of the Red Squirrel is higher than in smaller parks, with young and monoculture tree stands, isolated from other timbered areas. Habitat fragmentation caused by the construction of roads, buildings etc. may further contribute to the decline and even to the local extinction of the squirrel.

The average size of Red Squirrel's territory is related to the habitat, season of the year, reproductive activity and seed abundance. The male holds usually larger territory than the female. In England, this average ranges from 2.2 to 19.7 ha for female, and 6.2-31.4 ha for male. Territories may, however, overlap in large extend, especially in habitat abundant in food 


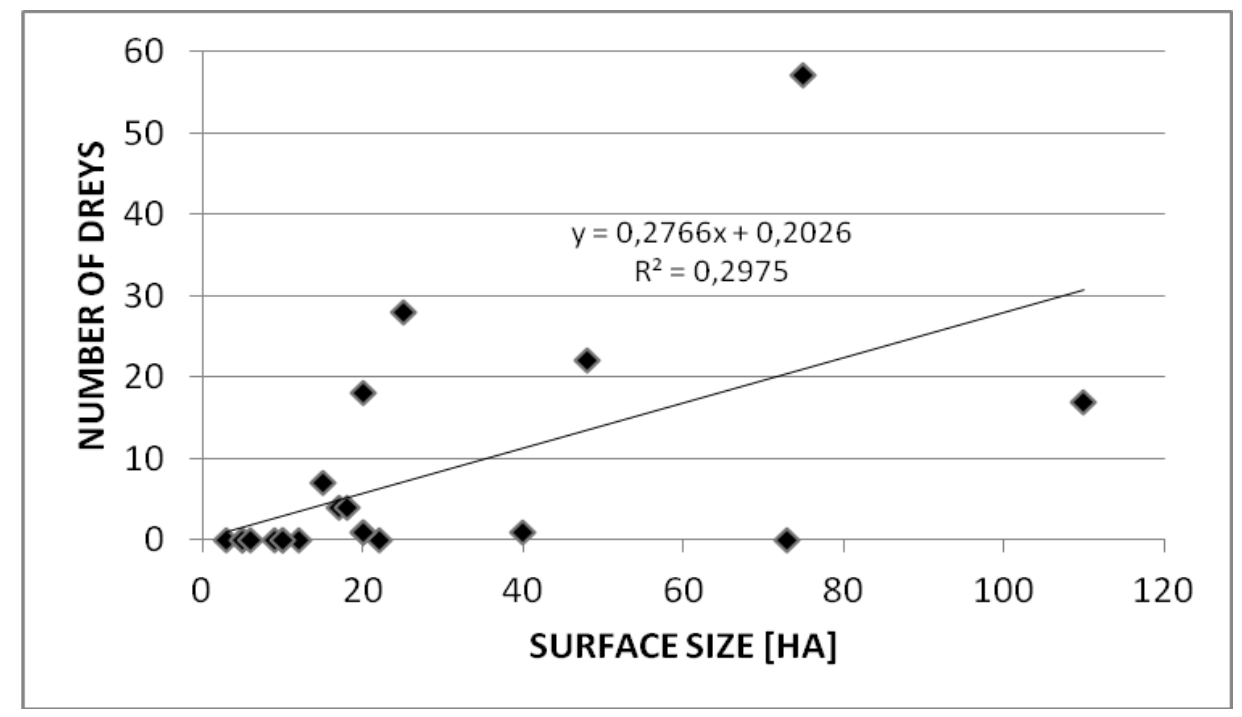

Fig 2: Correlation between the number of dreys and the park’s surface size.

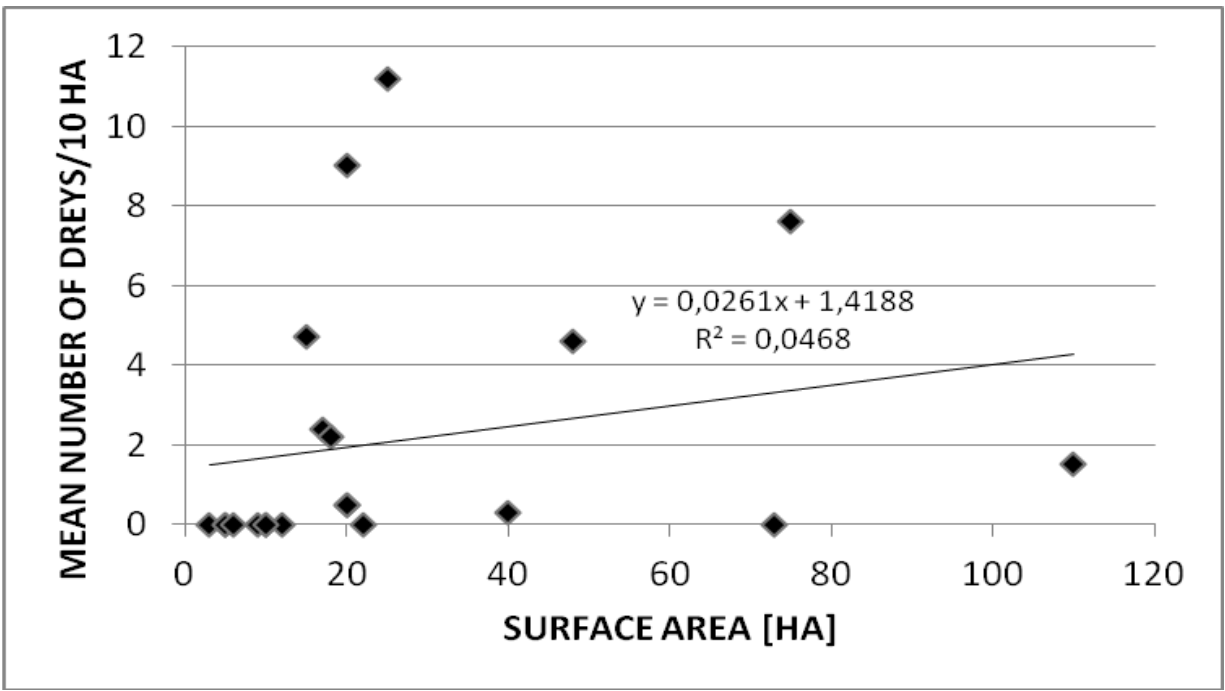

Fig 3: Correlation between the mean number of dreys/10 ha and the parks surface size.

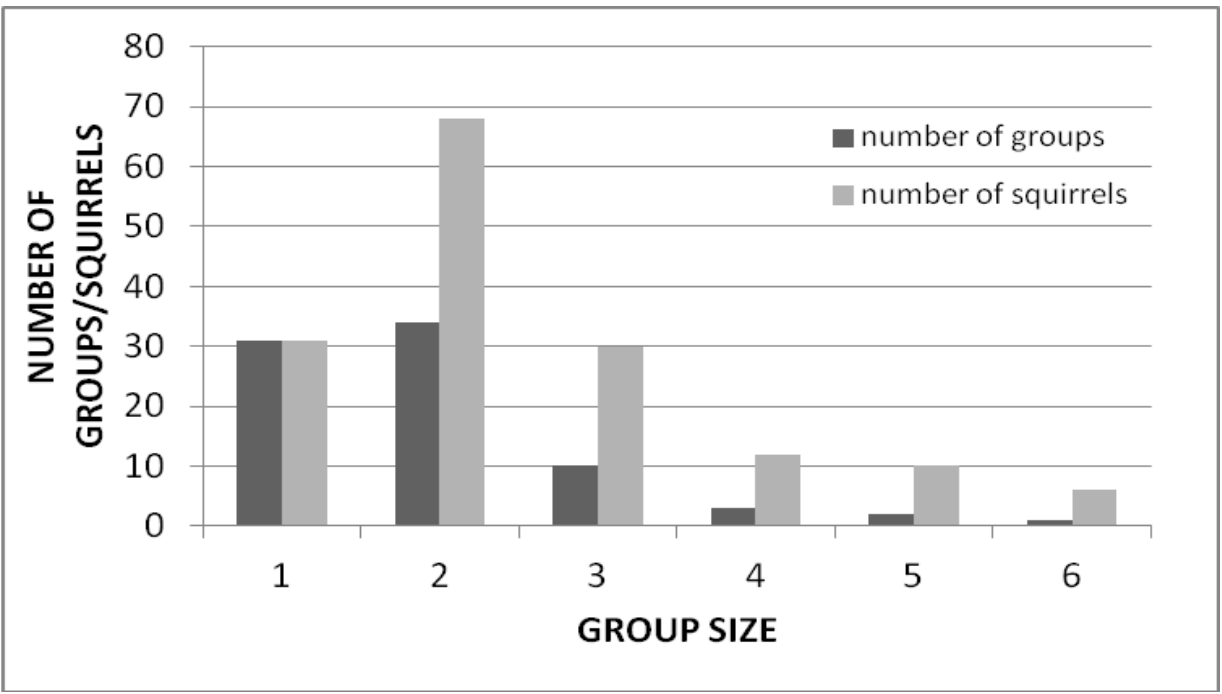

Fig 4: Group size of squirrels recorded in Wrocław in 2004-2005. 
(Lurz et al. 2005). In Wrocław parks the territory may range between 2 and 40 ha; on average 8.2 ha. In forests it is probably much larger.

Feeding the squirrels by people, especially with walnuts, so a widespread and common human habit in Wroclaw parks, may have both positive and negative effect on the squirrel population size. In some parks (e.g. Andersa, Skowroni, Park Szczytnicki, Biskupiński) this may increase the squirrel population size, but some intensively fed females may not reproduce (too high local density). Feeding by human may also contribute to the spread of parasites and diseases (Lurtz et al. 2005).

In other Silesian cities and towns, population density of the Red Squirrel has not been hitherto estimated. During the years 2002-2010, the Red Squirrel's presence was, however, recorded in larger parks in Opole, Nysa, Prudnik, Brzeg, Świdnica, Legnica, or Syców (own observations). It appears, however, that in none of these cities, the Red Squirrel is so numerous as in Wroclaw parks. In smaller Silesian towns, such as Korfantów, Niemodlin, Paczków, Otmuchów, Biała or Głogówek, it has not been recorded at all (own data).

\section{References}

Babińska-Werka J. \& Żółw M. (2008): Urban populations of the red squirrel (Sciurus vulgaris) in Warsaw. Ann. zool. fenn., 45: 270-276.

Borkenhagen K. (2000): Untersuchungen an Eichhörnchennestern. - Faunistisch-Ökologische Mitteilungen 8: $1-7$.

Fornasari L., Casale P. \& Wauters L. (1997): Red squirrels conservation: the assessment of a conservation experiment. - Ital. J. Zool. 64: 163-167.

Gurnell J., Lurz P.W.W. \& Halliwell E.C. (2008): Red squirrel Sciurus vulgaris; p. 57-66. In: Harris S., Yalden D. W. (eds). Mammals of the British Isles Handbook. $4^{\text {th }}$ ed. The Mammal Society, New Road, Southampton.

Gurnell J., Lurz P.W.W., Pepper H.W. (2001): Practical techniques for surveying and monitoring squirrels. Research Info. Note, Forest Commission Research Division 11, 12 pp.

Gurnell J., Lurz P.W.W., Shirley M.D.F., Cartmel S., Garson P.J., Magris L. \& Steele J. (2004): Monitoring red squirrels Sciurus vulgaris and grey squirrels Sciurus carolinensis in Britain. - Mammal Rev. 34: 51-74.

Gurnell J., Pepper H.W. (1991): Conserving the red squirrel. Research Info. Note, Forest Commission Research Division 205, 4 pp.

Kopij G. (2004): Ptaki lęgowe Wielkiej Wyspy Szczytnickiego Zespołu Przyrodniczo-Krajobrazowego we Wrocławiu. - Zesz. nauk. Akademii Rolniczej we Wrocławiu 488: 187-204.

- (2005): Ptaki lęgowe zachodniej części Śródmieścia we Wrocławia. - Zeszyty Naukowe AR Wrocław, Ser. Zootechnika 53: 87-99.

- (2007): Ptaki lęgowe Starego Miasta we Wrocławiu. - Zeszyty Naukowe UP we Wrocławiu, Biologia i Hodowla Zwierząt 55: 93-105.

- (2009): Habitat and drey of the red squirrel Sciurus vulgaris Linnaeus 1758 in suburban parks of Wrocław, SW Poland. - Acta zool. cracov. 52A: 107-114.

- (2010): Ptaki lęgowe północno-wschodniej części dzielnicy Fabrycznej we Wrocławiu. - Zeszyty Naukowe UP Wrocław, Biologia i Hodowla Zwierząt 60: 77-96.

Kopij G. \& Zendwalewicz M. (2009): Awifauna lęgowa Ogrodu Botanicznego we Wrocławiu. - Zeszyty Naukowe UP we Wrocławiu, Biologia i Hodowla Zwierząt, 58: 105-119.

Lurz P.W.W., Garson P.J. \& Wauters L.A. (2000): Effect of temporal and special variations in food supplies on the space and habitat use of the red squirrel (Sciurus vulgaris L.). - J. Zool. 251: 167-178.

Lurz P.W.W., Gurnell J. \& Magris L. (2005): Sciurus vulgaris. - Mammalian Species, 769, 10 pp.

Pucek Z. \& Raczynski J. (eds) (1983): Atlas rozmieszczenia ssaków w Polsce. Warszawa, PWN.

Tomiałojc L. (2011): Changes in breeding bird communities of two urban parks in Wrocław across 40 years (1970-2010): before and after colonization by important predators. - Ornis Polonica 52: 1-25.

Wauters L.A., Currado I., Mazzoglio P.J. \& Gurnell J. (1997): Replacement of red squirrels by introduced grey squirrels in Italy: evidence from a distribution survey, pp. 79-88. In: Gurnell J. \& Lurz P.W.W. (eds). The conservation of red squirrels, Sciurus vulgaris L. People's Trust for Endangered Species, London.

Wauters L.A., Gurnell J., Preatoni D. \& Tosi G. (2001): Effects of spatial variation in food availability on spacing behaviour and demography of Eurasian red squirrels. - Ecography 24: 525-538. 
Wauters L.A., Lurz P.W.W. \& Gurnell J. (2000): The effect of interspecific competition by grey squirrels (Sciurus carolinensis) on the space use and population of red squirrels (Sciurus vulgaris) in conifer plantations. - Ecological Research 15: 271-284.

Author's address: Grzegorz Kopij, Department of Wildlife Management, University of Namibia, Katima Mulilo Campus, Private Bag 1096, Winela Rd, Katima Mulilo, Namibia

e-mail: gkopij@unam.na 